\title{
In vivo Analgesic activity of methanolic extract of Helianthus annuus seeds
}

\author{
*Rubab Tarannum Islam ${ }^{1}$, Ahmed Tanjimul Islam ${ }^{2}$, Mir Monir Hossain ${ }^{1}$ and Kishor Mazumder ${ }^{1}$ \\ ${ }^{1}$ Department of Pharmacy, University of Science and Technology Chittagong (USTC), Chittagong- 4202, Bangladesh \\ ${ }^{2}$ Department of Neurology, Chittagong Medical College and Hospital, Chittagong- 4203, Bangladesh
}

\begin{abstract}
The sunflower seed is the seed of the sunflower (Helianthus annuus). The methanol extract of seeds of Helianthus annuus were screened for analgesic activity in mice model to systematically explore the medicinal values of the plant. Acetic acid induced writhing and hot plate methods were used to confirm the central and peripheral analgesic action. In case of acetic acid-induced writhing test the extract showed significant $(\mathrm{P}<0.05)$ analgesic potential at doses 100 and $200 \mathrm{mg} / \mathrm{kg}$ body weight $(50.35$ and $57.85 \%$ inhibition, respectively). In the hot plate method, increase $(\mathrm{p}<0.05)$ of latency period was also observed in comparison to standard aspirin. At 60 minutes, the latency period of two different doses (100 and $200 \mathrm{mg} / \mathrm{kg}$ body weight) was found at $13 \pm 0.91$ and $16.5 \pm$ 1.55 second. The results obtained support the use of Helianthus annuus seeds in painful conditions acting both centrally and peripherally.
\end{abstract}

Key Words: Helianthus annuus, asteraceae, analgesic, writhing method, hot plate test.

\section{INTRODUCTION}

The sunflower seed is the fruit of the sunflower (Helianthus annuus, family: Asteraceae). The term "sunflower seed" is actually a misnomer when applied to the seed in its pericarp (hull). These seeds are usually pressed to extract their oil. It is a potential protein supplement for human diet with rich source of vitamins specially vitamin E. Pain is an unpleasant sensation that can range from mild, localized discomfort to agony. The treatment of pain includes opioids and non-opioids drug like steroidal and non-steroidal anti-inflammatory drugs (NSAIDS) and neuropathic agents. Different types of adverse effects are confronted with the regular use of these drugs ( $\mathrm{Su}$ et al., 2012; Yu et al., 2012). Plants can be used as a great source of medicinal agents in pain management for safety and comfort of the patients. Drugs which are used as analgesic, causes analgesia or reduces pain by acting on the pain pathway of central nervous system at neurotransmitter level. Synthetic analgesic drugs may result several adverse effects including GI upset, peptic ulcer, gastrointestinal bleeding etc. There are very few reports found that describe the scientific justification supporting the traditional use of Helianthus annuus seed. For these reason this study was done to investigate the analgesic activity of the seed extract of Helianthus annuus plant using mice models.

\section{MATERIALS AND METHODS}

\section{Animal}

Swiss albino male mice (22-25g) collected from BCSIR (Bangladesh Council of Scientific and Industrial Research), Chittagong, were used in the study. A constant temperature $\left(22 \pm 2^{\circ} \mathrm{C}\right)$ and 12-h light/12-h dark condition were kept for the mice. Mice were fed standard laboratory food (Hind Lever diet pellets) and water ad libitum. Each animal was used once in the behavior tests. The experi-

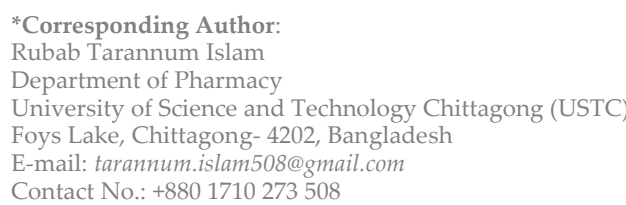

mental protocols for this study were approved by the Institutional Ethical Committee of University of Science and Technology Chittagong (USTC/2015/1830/02) following the guidelines of Committee for the Purpose of Control and Supervision of Experiments on Animals (CPCSEA).

\section{Plant material and extraction}

Dried powder of seed $(300 \mathrm{gm})$ was weighed and taken in an aspirator (2.5L). By using acetone the container was cleaned completely and then dried before placing powder of seed into the aspirator. $800 \mathrm{ml}$ of solvent i.e. methanol was added slowly. The content in the container was sealed and kept for 20 days by periodically shaking and stirring. In solvent, the major parts of extractable compounds of the plant materials were equally dissolved. Then, cotton wool was used to filter the mixture and the filtrate was concentrated by evaporation in dry and clean air. It was kept for 15 days to get the final extract of the seed.

\section{Phytochemical screening}

Preliminary Phytochemical screening of the powdered seed was performed for the presence of alkaloids, carbohydrates, flavonoids, steroid and triterpenoids (Trease and Evans, 1989) (table 1).

\section{Drugs and chemicals}

The following drugs and chemicals were used: Acetic acid (Merck, Germany), aspirin (Opsonin Pharma, Ltd.) and methanolic extract of Helianthus annuus seed.

\section{Acetic acid induced writhing}

Method described by Koster et al. (1959) was used for acetic acid induced writhing test. Methanolic extract (100 $\mathrm{mg} / \mathrm{kg}, 200 \mathrm{mg} / \mathrm{kg})$, aspirin $(10 \mathrm{mg} / \mathrm{kg}$ ) and normal saline $(10 \mathrm{ml} / \mathrm{kg})$ were given to four groups each containing respectively. Each mouse was given intraperitonial $0.7 \%$ acetic acid at a dose of $(10 \mathrm{ml} / \mathrm{kg})$ body weight after duration of 45 minutes. During a subsequent $5 \mathrm{~min}$ period after 15 min intraperitonial administration of acetic acid, the number of writhing responses counted for each mice 
and the mean abdominal writhing was obtained for each mice group. By using the following formula the percentage inhibition was recorded -

$\%$ Inhibition $=\frac{\text { Mean number of writhing (control) }- \text { Mean number of writhing (drugs) }}{\text { Mean number } 0 \text { writhing (control) }}$ Mean number of writhing (control)

\section{Hot plate method}

The method described by Eddy and Leimbach (1953) was employed to calculate the response latency in hot plate method. $55 \pm 2^{\circ} \mathrm{C}$ temperature was kept in this method (Ugo Basile, Italy, model 7280). Four groups of 4 mice were taken. The control group (group 1) was given normal saline, p.o., the standard group (group 2) was given aspirin $(10 \mathrm{mg} / \mathrm{kg})$. Both group 3 and 4 was given crude extract $(100 \mathrm{mg} / \mathrm{kg}, 200 \mathrm{mg} / \mathrm{kg})$, and mice were taken into a Perspex cylinder on a heated surface. The latency response was recorded by counting the time between placement of the mice on the hot plate discomfort, which indicated by either paw licking or jumping off the surface. The baseline latencies in mice of more than 10 s were excluded from the experiment and the cut-off time was set at 15 second. After administration of test solution the latency of discomfort was calculated at 0,30 , 60,90 and 120 minutes.

\section{Statistical analysis}

The results were expressed as mean \pm S.E.M. Statistical software SPSS version 16 was used and ANOVA test was done for statistical analysis of difference between groups. The $p$ value less than 0.05 were considered significant.

\section{RESULTS}

\section{Response in acetic acid induced writhing}

$0.7 \%$ acetic acid was given intra peritoneally to all three groups (Control, Aspirin, Helianthus annuus of 100 and 200 $\mathrm{mg} / \mathrm{kg}$ body weight) to assess the acetic acid induced analgesic activities. The writhing was counted accordingly and writhing of control group was assumed to be $100 \%$. The writhing of control group was found $83 \pm 2.32$ whereas writhing of $31 \pm 1.20(62.21 \%$ inhibition) was found in positive control (aspirin) which is highly significant $(\mathrm{P}<0.01)$. The experimental group $200 \mathrm{mg} / \mathrm{kg}$ body weight dose group showed writhing with $27.6 \pm 2.65(57.85 \%$ inhibition) which is significant than $100 \mathrm{mg} / \mathrm{kg}(41.6 \pm 0.63$, $50.35 \%$ inhibition) (table 2).

\section{Response in hot plate method}

Results of hotplate test are presented in table 3 for the crude extracts of $H$. annuus seed. The extracts of the seeds were found to exhibit a dose dependent increase in latency time when compared with standard. At 60 minutes, the latency period of two different doses (100 and $200 \mathrm{mg} / \mathrm{kg}$ body weight) was $13 \pm 0.91$ and $16.5 \pm 1.55$ second for $H$. annuus. The results were found to be statistically significant $(\mathrm{p}<0.05)$.
Table 1: Phytochemical screening test of Helianthus annuus seeds.

\begin{tabular}{llc}
\hline Phytochemicals & Test & Inference \\
\hline Carbohydrates & Fehling's test & + \\
Alkaloids & Wagner's test & + \\
Flavonoids & Alcoholic test & + \\
Tannins & Ferric chloride test & - \\
Glycosides & Keller-Killiani test & - \\
Saponins & Foam test & - \\
Steroids & Libermann-Burchard test & + \\
Triterpenoids & Libermann-Burchard test & + \\
Gum & Molisch's test & - \\
\hline$+^{\prime}=$ Present; '-'= Absent &
\end{tabular}

${ }^{\prime}{ }^{\prime}=$ Present; ${ }^{\prime}{ }^{\prime}=$ Absent

Table 2: Response in acetic acid induced writhing in mice.

\begin{tabular}{lcccc}
\hline Groups & Treatment & Dose $(\mathbf{m g} / \mathbf{k g})$ & $\begin{array}{c}\text { No. of } \\
\text { writhing }\end{array}$ & $\begin{array}{c}\text { Percent } \\
\text { inhibition }\end{array}$ \\
\hline Group I & Water & $0.4 \mathrm{ml} / \mathrm{mouse}$, p.o & $83 \pm 2.32$ & - \\
Group II & Aspirin & $10 \mathrm{ml} / \mathrm{kg}$, p.o. & $31 \pm 1.20$ & 62.21 \\
Group III & H. annuus & $100 \mathrm{mg} / \mathrm{kg}$, p.o. & $41.6 \pm 0.63$ & 50.35 \\
Group IV & H. annuus & $200 \mathrm{mg} / \mathrm{kg}$, p.o. & $27.6 \pm 2.65$ & 57.85 \\
\hline
\end{tabular}

\section{DISCUSSION}

The hot plate method which measures the complex response to a nociceptive signal is considered to be selective for the central acting analgesic drugs. Release of free arachidonic acid from tissue phospholipid) via cyclooxygenase (COX), and prostaglandin biosynthesis in pain sensation which is released by local inflammatory response can be measured by acetic acid induced writhing method (Ahmed et al. 2006; Duarte et al., 1988). In other words, the acetic acid induced writhing has been associated with increased level of prostaglandines E2 and prostaglandins F2 $\alpha$ in peritoneal fluids (Derardt et al., 1980). By increasing capillary permeability the rise in prostaglandin levels within the peritoneal cavity then enhances inflammatory pain (Zakaria et al., 2008). It has been previously reported that flavonoids have a role as analgesic as it targets the prostaglandins (Rajnarayana et al. 2001; Rao et al., 1998). So, the pain modulation of the plant extract might be for the analgesic principles acting with the prostaglandin pathways. So in comparison to the reference drug aspirin our study of crude extract of plants showed significant analgesic action.

Role of tannins in anti-nociceptive activity was previously reported (Vanu et al., 2006). It is also an established fact that alkaloids have significant effect in inhibition of pain sensation (Uche et al., 2008). The extracts of the plants and aspirin $(10 \mathrm{mg} / \mathrm{kg})$ also showed a higher latency time compared to control group in the hot plate method in a dose related manner.

The methanolic extract of helianthus annuus has phytochemical component like alkaloids, tanins, saponins and terpenoids. So, because of presence of tannins and alkaloids in the extract are the main reason for the analgesic activity, which has been reported as an antianalgesic constituent (Vanu et al., 2006; Uche et al., 2008).

Table 3: Response in hot plate method in mice.

\begin{tabular}{ccccccc}
\hline \multirow{2}{*}{ Group } & \multirow{2}{*}{ Dose $\mathbf{( m g} / \mathbf{k g})$} & Initial & \multicolumn{4}{c}{ Latency time to pain response during treatment in seconds } \\
\cline { 3 - 7 } & & 2 & $\mathbf{3 0}$ minute & $\mathbf{6 0}$ minute & $\mathbf{9 0}$ minute & $\mathbf{1 2 0}$ minute \\
\hline Control & - & $1.75 \pm 0.22$ & $2 \pm 0.365$ & $1.75 \pm 0.43$ & $2.5 \pm 0.26$ \\
Aspirin & 10 & $10.25 \pm 0.475$ & $18 \pm 0.41$ & $24.25 \pm 0.625$ & $20.75 \pm 0.475$ & $19 \pm 0.705$ \\
Helianthus annuus & 100 & $7.5 \pm 0.865$ & $8 \pm 0.408$ & $13 \pm 0.91$ & $9 \pm 0.705$ & $6.5 \pm 0.705$ \\
Helianthus annuus & 200 & $8 \pm 0.408$ & $9.75 \pm 0.475$ & $16.5 \pm 1.55$ & $13 \pm 0.915$ & $10.5 \pm 0.915$ \\
\hline
\end{tabular}




\section{CONCLUSION}

The results of our investigation concluded that methanolic extract of Helianthus annuus possesses analgesic property indicating the presence of pharmacologically active compounds in the crude seed extract. These findings constitute the scientific basis of the traditional uses of the plant. Further studies are needed to confirm the activities, isolate the active compounds and explain the probable mechanisms related to these possible pharmacological effects.

\section{REFERENCES}

Ahmed F, Selim MST, Das AK, Choudhuri MSK (2004) Antiinflammatory and antinociceptive activities of Lippia nodiflora Linn. Pharmazie; 59: 329-333.

Ahmed M, Shikha HA, Sadhu SK, Rahman MT, Datta BK ( 2001) Analgesic, diuretic, and anti-inflammatory principle from Scoparia dulcis. Pharmazie; 56(8): 657-660. PMid:11534346

Derardt R, Jougney S, Delevalccee F, Falhout M (1980). Release of prostaglandins $\mathrm{E}$ and $\mathrm{F}$ in an algogenic reaction and its inhibition. European Journal of Pharmacology, 51: 17-24. [DOI]

Duarte, I.D., Nakamura, M., Ferreira, S.H. (1988) Participation of the sympathetic system in acetic acid-induced writhing in mice. Brazilian Journal of Medicine and Biological Research; 21: 341-343. PMid:3203167
Eddy, N. B. and Leimbach, D (1953). Synthetic analgesics. II. dithienylbutenyl and dithienylbutylamines. J. Pharmacol. Exp. Ther; 107, 385-393. PMid:13035677

Koster R, Anderson M, Debeer EJ (1959). Acetic acid for analgesic screening. Federation Proceedings; 18: 412.

Rajnarayana K, Reddy MS, Chaluvadi MR, Krishna DR (2001). Biflavonoids classification, pharmacological, biochemical effects and therapeutic potential. Indian Journal of Pharmacology;33: 2-16.

Su, S., Hua, Y., Wang, Y., Gu, W., Zhou, W., Duan, J.A., Jiang, H., Chen, T. and Tang, Y (2012). Evaluation of the anti-inflammatory and analgesic properties of individual and combined extracts from Commiphora myrrha and Boswellia carterii. J. Ethnopharmacol.;139, 649-656. [DOI]

Trease GE, Evans WC (1989). Pharmacognosy. W.B Scandars Company Ltd. London;14: 269-300.

Vanu, M.R., Palanivelu, S., Panchanatham, S. (2006) Immunomodulatory and anti-inflammatory effects of Semecarpus anacardium Linn. Nut milk extract in experimental inflammatory conditions. Biological and Pharmaceutical Bulletin; 29: 693-700. [DOI]

Yu, C.H., Tang, W.Z., Peng, C., Sun, T., Liu, B., Li, M., Xie, X.F. and Zhang (2012), H. Diuretic, anti-inflammatory and analgesic activities of the ethanol extract from Cynoglossum lanceolatum. J. Ethnopharmacol.139, 149-154. [DOI]

Zakaria ZA, Abdul Gani ZDF (2008). Antinociceptive, anti-inflammatory, and antipyretic properties of an aqueous extract of Dicranopteris linearis leaves in experimental animal models. Journal of Natura Medicines; 62: 179-187. [DOI] 